International Journal of Social Sciences and Humanities
Available online at http://sciencescholar.us/journal/index.php/ijssh
Vol. 3 No. 3, December 2019, pages: $90 \sim 98$
e-ISSN: 2550-7001, p-ISSN: 2550-701X
https://doi.org/10.29332/ijsh.v3n3.362

\title{
Methodological Strategies Used in the Learning of Mathematics in the 8th Year of EGB
}

\author{
CrossMark

\begin{abstract}
Dubal Edisson Salvatierra Tumbaco a, William Ecuador Martínez Albán ${ }^{\text {b }}$, María José Briceño Ruperti ${ }^{c}$, David Eloy Palma Palacios ${ }^{\mathrm{d}}$
\end{abstract}

Article history: Received 09 April 2019, Accepted: 31 August 2019, Published: 20 November 2019

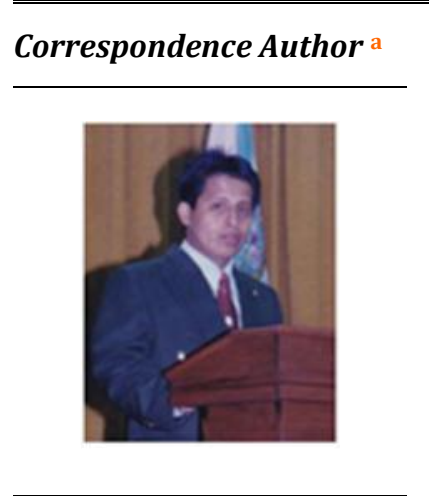

Keywords

learning;

mathematics;

school performance;

strategies;

teaching;

\begin{abstract}
This research is based on the use of learning strategies that allow you to improve the academic performance of students in the 8th year of Basic Education in the Mathematics course. For a long time, the study of mathematics has been presented as a complicated and tedious activity that prevents the inter-learning of students, causing poor academic performance. For this reason, it was necessary to investigate the different learning strategies, which can be applied in the subject of mathematics, based on contemporary pedagogical currents that contribute to raising the academic level in students. It is worth noting that there are several variables that influence the low school performance, such as personal, institutional, and social environment that marks the student's learning process, by virtue of what has been said above, it is sought to define what would be the characteristics of those variables that determine school failure or success. For this, a theoretical foundation was reviewed, from which a conceptual analysis was carried out, on the different factors that condition school performance. An investigation was also carried out on a part of the population, applying a survey to then tabulate and analyze the results, which will allow us to present the research conclusions and the respective recommendations.
\end{abstract}

e-ISSN: 2550-7001, p-ISSN: 2550-701X ๑ Copyright 2019. The Author. SS Journals Published by Universidad Técnica de Manabí. This is an open-access article under the CC BY-SA 4.0 license (https://creativecommons.org/licenses/by-sa/4.0/) All rights reserved.

\section{Contents}

Abstract

1. Introduction.

2. Materials and Methods.

a Pontificia Universidad Católica del Ecuador, Portoviejo, Manabí, Ecuador

b Pontificia Universidad Católica del Ecuador, Portoviejo, Manabí, Ecuador

c Pontificia Universidad Católica del Ecuador, Portoviejo, Manabí, Ecuador

d Universidad Nacional de Educación a Distancia (UNED), Madrid, Spain 


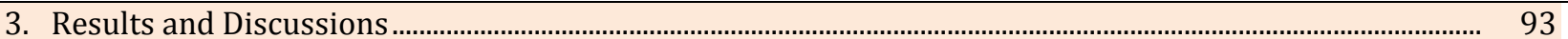

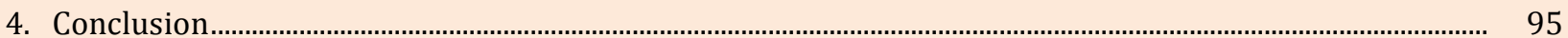

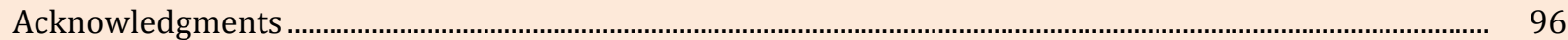

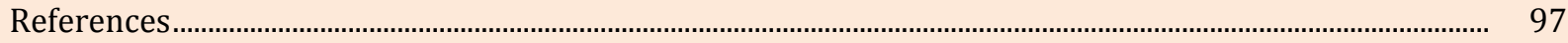

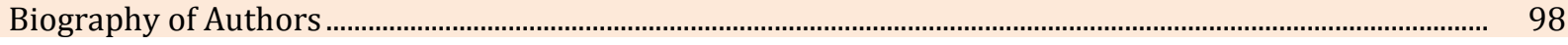

\section{Introduction}

Studying mathematics is an issue that has always been discussed by many authors, who have sought the appropriate techniques and strategies, so that students arouse interest in the subject, with favorable results. The evolution of mathematics has been at the same pace that human civilization, with the contribution of people who came from many cultures, have generated ideas that have been used for more than 4000 years (Ian, 2007). This is a subject that has its origin, from the first primitive communities that tried to express the concept of the number of different forms, found in some ancient writings and explained by scientific researchers of this science.

With the passage of time, this field of knowledge evolved, and subject scholars have been discovering new methodological strategies that improve the learning of mathematics. Mathematics is an expression of the human mind, which reflects the active will, the contemplative reason, and the desire for aesthetic perfection (Courant Richard, 2013; Mahendra, 2016). For this reason these are fundamental, for the intellectual development of the child in its first years of life, it helps them to be logical and orderly, allowing them to reason properly and have the mind prepared for: critical thinking, and abstraction (Godino Juan et al., 2013; Mahayukti et al., 2017).

Related to learning is an academic performance, which according to Beneyto (2015), refers to the results obtained over a period of time and determines the level of studies achieved. In this academic performance several subjects are involved, such as students, teachers, parents, that if each one contributes with the necessary and corresponding in this process, we will see the desired success in learning (Morales, 2010). When the expected results are not achieved according to the plans and programs established in a given time, there are low academic returns, produced by different causes such as family support, student work in the classroom, among others, which also were raised by (Solarte, 2016).

There are other authors who have worked the teaching-learning process using different methodologies that can contribute to this process. We can mention the learning focused on research processes (Mendoza \& Rodríguez, 2019), other work that promotes Neuroeducation as pedagogical assistance in learning (Ceballos \& Rodríguez, 2019; Alava et al., 2018). In the teaching process also involved the concepts related to the brain that learns, where the student modifies cognitive processes and in the subject of mathematics where knowledge is logical and analytical the students are creative and manage to demonstrate their learning of the subject of mathematicians, Results have been experienced in parishes demonstrating that many cognitive problems can be solved (Bastidas et al., 2019; Widana et al., 2018).

The Teaching-learning process is an activity through which new knowledge is built, and skills and abilities are acquired. According to Alvarez (2017), so that in this teaching-learning process the academic performance is favorable and the main protagonist is the student and the teacher fulfills a facilitator function, methodological strategies need to be applied, which help to improve the inter-learning, where students can develop all their potential in the study of mathematics.

This research was carried out in the Millennium Education Unit "Replica" Manta in the city of Manta. The objective was to know the methodological strategies used to improve student learning. According to Diaz (2015), the Teaching - Learning strategies are: the means or resources to facilitate the pedagogical process with the student, and achieve meaningful learning. This should be applied according to the moment in which learning occurs, among them are observed in figure 1.

Tumbaco, D. E. S., Albán, W. E. M., Ruperti, M. J. B., \& Palacios, D. E. P. (2019). Methodological strategies used in the learning of mathematics in the 8th year of EGB. International Journal of Social Sciences and Humanities, 3(3), 90-98. https://doi.org/10.29332/ijssh.v3n3.362 


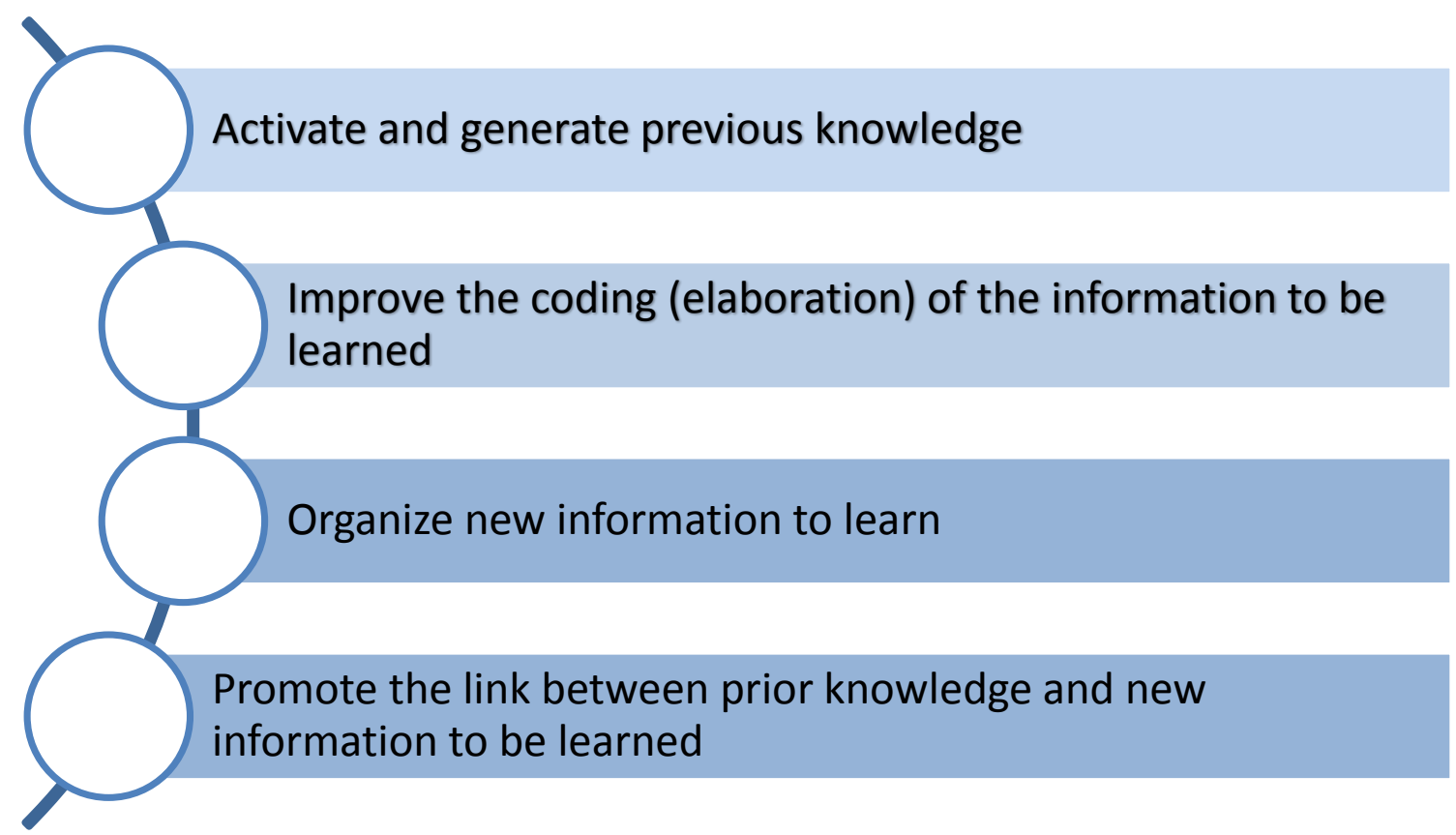

Figure 1. Teaching strategies - learning

These strategies have different methodological features that stand out in different actions shown in figure 2.

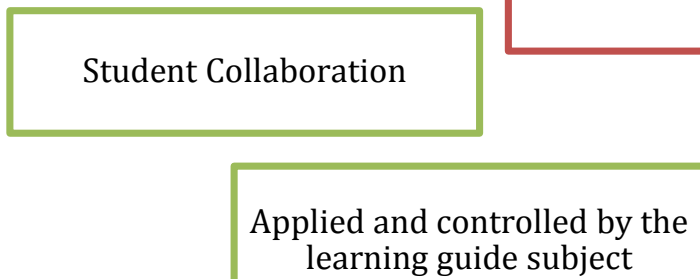

learning guide subject

\section{Actions}

Logical sequence

Figure 2. Methodological actions

All these strategies and methodologies have helped to improve students' academic performance, and surely the level of knowledge in the area of mathematics (Abellas, 2015). This research is aimed at verifying and determining the causes of the low academic level that students of the 8th year of basic education have in the Mathematics subject, and what would be the learning strategies that allow them to improve that academic level.

\section{Materials and Methods}

The survey was used as an instrument to know how these aspects behaved in school. The scientific, synthetic analytical method was applied, which allowed deepening the theoretical elements, referring to the topic of research. Murray's equation was used to calculate the sample to be shown in (1). 


$$
\begin{aligned}
& \mathrm{n}=\frac{\left(Z^{2}\right)(P)(Q)(N)}{\left(Z^{2}\right)(P)(Q)+(N)\left(e^{2}\right)} \\
& \mathrm{n}=70
\end{aligned}
$$

Where:

$\mathrm{n} \rightarrow$ Sample size

$\mathrm{Z} \rightarrow 95 \%$ reliability level $=(1.96)$

$\mathrm{p} \rightarrow$ Probability of success $=(0.5)$

$\mathrm{q} \rightarrow$ Probability of failure $=(0.5)=(0.5)$

$\mathrm{N} \rightarrow$ Population size $=(245)$

$\mathrm{e} \rightarrow$ Error de muestreo $=(0,1)$

The sample to be evaluated was 70 students from the 8th year of basic general education.

\section{Results and Discussions}

Methodological strategies help to improve the teaching-learning process in the students of the mathematics subject, allowing them to develop their critical and reflexive capacity, promoting a better academic performance (Alvares, 2017).

In figure 3, the results on the application of renewed methodological strategies can be observed, where we are shown that $77 \%$ of respondents do apply this type of strategy in the teaching-learning process and $23 \%$ do not apply it.

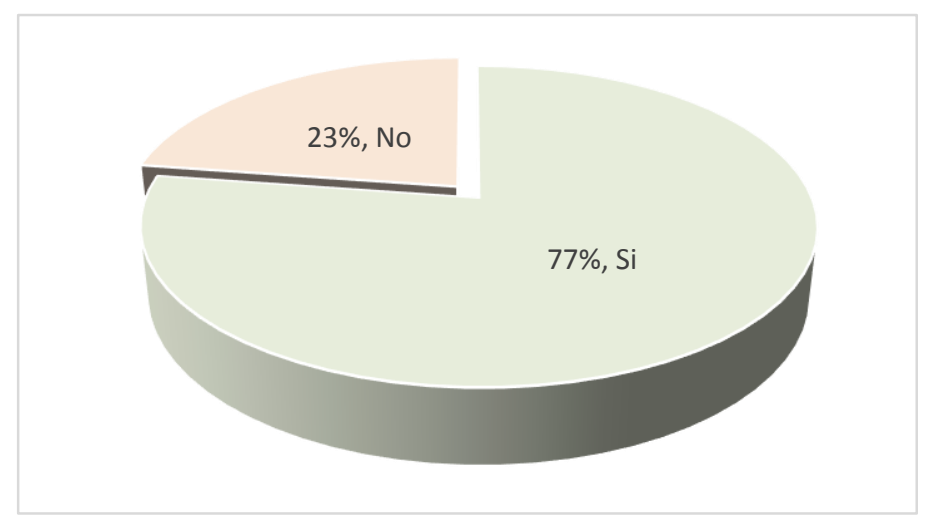

Figure 3. Application of methodological strategies Source: UEM “Replica” Manta

In Figure 4, the results are shown about the opportune moment in which the methodological strategies should be applied by the teacher to the students, most agree that they should be applied at the beginning and during the development of a learning topic, leaving some for the closing of the study topic.

Tumbaco, D. E. S., Albán, W. E. M., Ruperti, M. J. B., \& Palacios, D. E. P. (2019). Methodological strategies used in the learning of mathematics in the 8th year of EGB. International Journal of Social Sciences and Humanities, 3(3), 90-98. https://doi.org/10.29332/ijssh.v3n3.362 


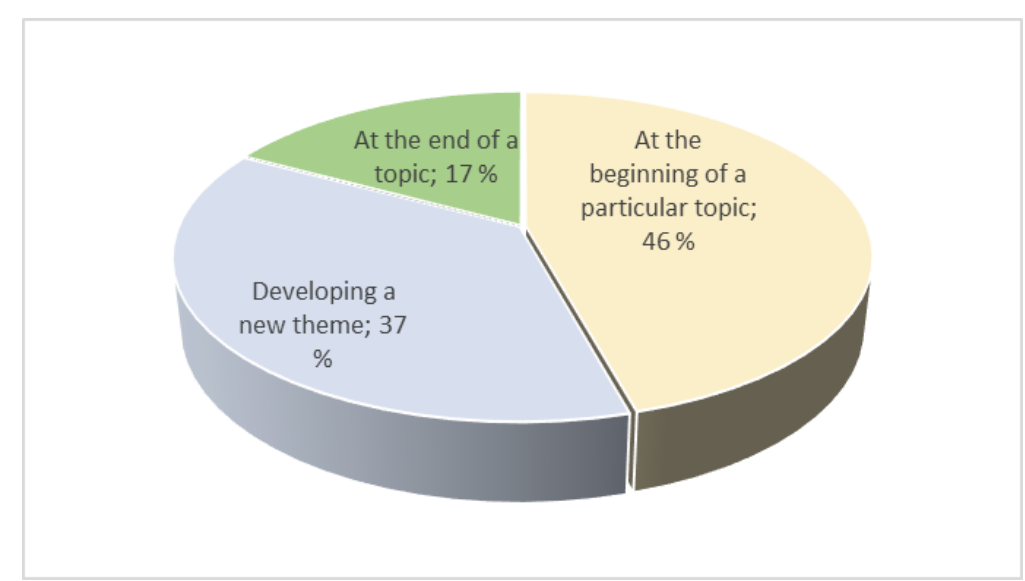

Figure 4. Time of application of methodological strategies Source: EMU “Replica” Blanket

As you can see, the largest number of respondents coincides with $46 \%$ that should be applied at the beginning of a particular time. In figure 5, the results on the usefulness of applying the methodological strategies to the students are visualized, and the responses of the respondents agreed in a (50\%) that these strategies are used to activate previous knowledge, another $40 \%$ to strengthen the development of a theme, and $10 \%$ as a starting point for new knowledge. This indicates that active methodological strategies are of vital importance throughout the learning process.

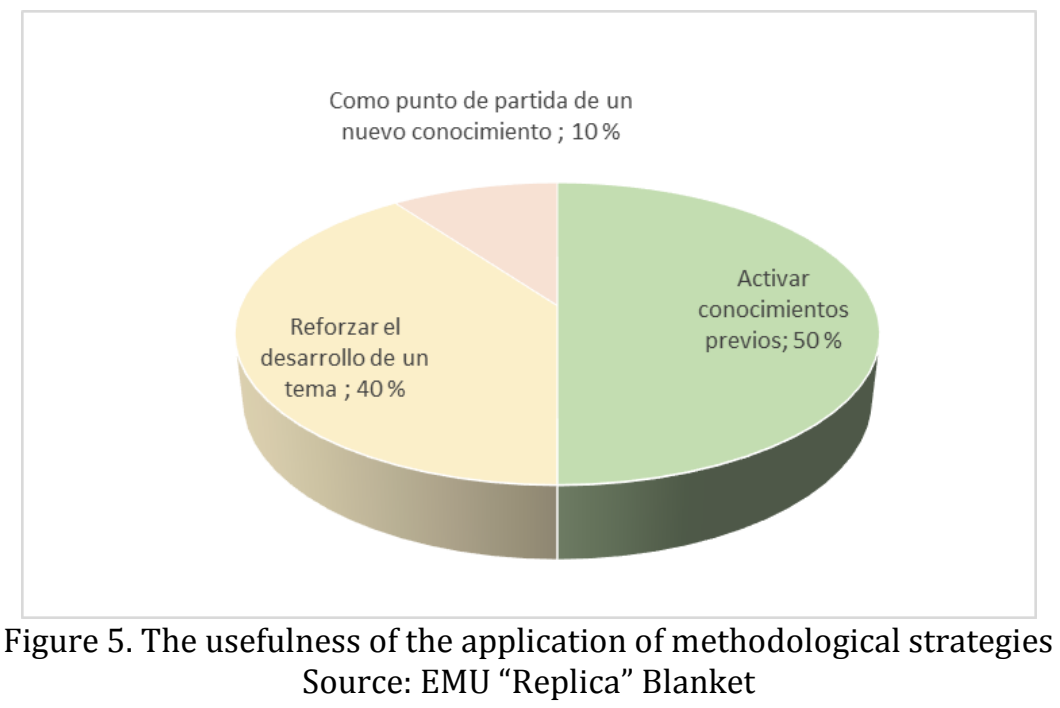

It is also found in relation to the type of strategy to be used, in figure 6, it is shown how they consider that descriptive methodologies should be applied since in mathematics the logic is used for the different analyzes. These responses indicate that the types of methodologies are varied according to the topic and time of the study. 


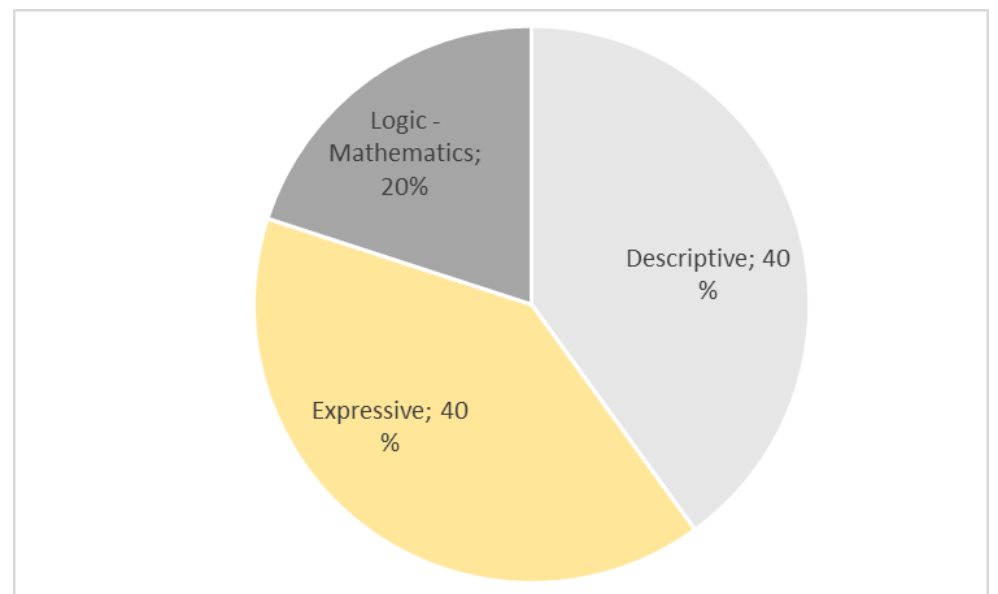

Figure 6. Types of methodological strategies to be applied Source: EMU “Replica” Blanket

To analyze the usefulness of the results obtained in the application of the surveys related to the active methodological strategies, the answers were in accordance with the percentages shown in Figure 7 where $37 \%$ allows you to determine the level of initial knowledge of the students, another $50 \%$ allows you to activate multiple intelligences in the learning process, $13 \%$ allows you to make decisions according to the results obtained. The results indicate that learning strategies are of importance in the process of knowledge construction itself.

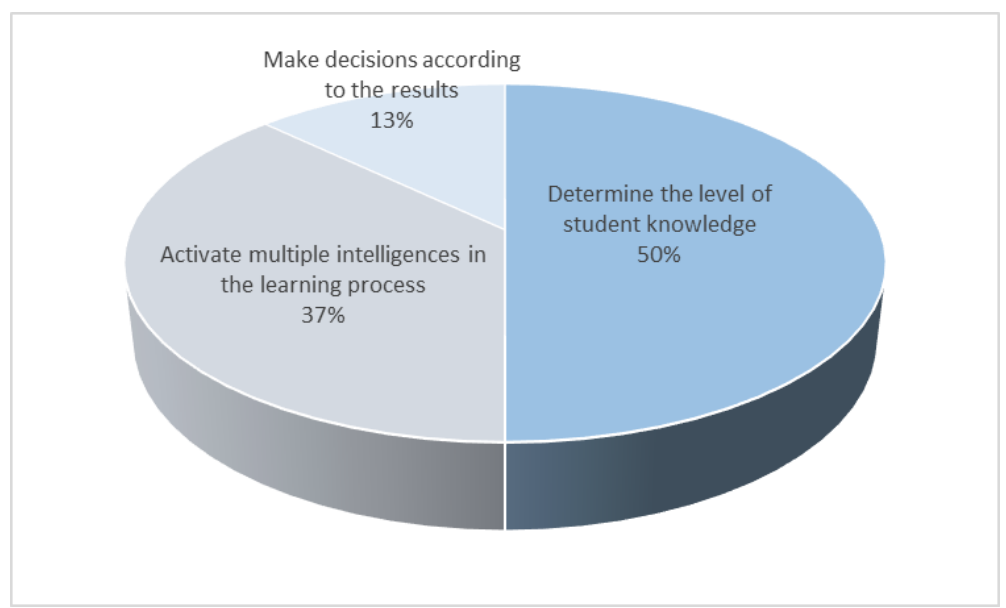

Figure 7. Results of the application of methodological strategies Source: EMU “Replica” Blanket

Most of the teachers surveyed stated that if the methodological strategies should be applied in their teachinglearning process, all of them applied the methodology at different times, of the development of a class theme.

\section{Conclusion}

These strategies allow them to activate previous knowledge, develop a study topic, and close it successfully, by using various types of methodological strategies according to the development of the class topic, it is necessary to reinforce the new strategies, which have enabled activation multiple intelligences, to perform meaningful learning.

Tumbaco, D. E. S., Albán, W. E. M., Ruperti, M. J. B., \& Palacios, D. E. P. (2019). Methodological strategies used in the learning of mathematics in the 8th year of EGB. International Journal of Social Sciences and Humanities, 3(3), 90-98. https://doi.org/10.29332/ijssh.v3n3.362 
Acknowledgments

Special recognition is made to the group of authors who have collaborated in this research with the objective of perfecting student learning. 
References

Abellas, M. P. (2015). Methodologies in the teaching of mathematics. Jaumet University.

Alava, L. A. C., Castillo, G. A. L., Macias, J. C. M., Segarra, J. C. G., \& Molina, L. A. V. (2018). Energy analysis for designing photovoltaic power plant in building of the faculty of mathematics. International Journal of Physical Sciences and Engineering, 2(3), 10-22. https://doi.org/10.29332/ijpse.v2n3.192

Alvares, B. N. (2017). Methodological strategies for learning mathematics, in the 7th year of EGB, of the UECIB Quilloac. Basin, watershed, catchment area, socket, bowl, hollow.

Bastidas, C., Guale, B., Moya, M. \& Rodríguez, M. (2019). Problemas de aprendizaje en el contexto educativo de la parroquia cascol. International Journal of Social Science and Humanities. Vol. 3. (2). http://www.sciencescholar.us/journal/index.php/ijssh/index.

Beneyto, S. S. (2015). Family Environment and Academic Performance. Alzamora: Area of Innovation and Development, SL

Cevallos, Y. \& Rodríguez, M. (2019). Neuroeducación una tendencia pedagógica en el aprendizaje para la vida. Cienciamatria. Vol. 6 (10). 547-559. DOI 10.35381/cm.v6i10.232.

Courant Richard, R. H. (2013). What is math Spain: Aguilar Ediciones.

Diaz, B. F. (2015). Teaching strategies for meaningful learning. Mexico: Threshing.

Godino Juan, Batanero Carmen, Font Vicenc. (2013). Mathematics and its Didactics for Teachers. Granada: Reprodigital.

Ian, S. (2007). History of Mathematics. lirosmaravillosos.com.

Mahayukti, G. A., Gita, I. N., Suarsana, I. M., \& Hartawan, I. G. N. Y. (2017). The effectiveness of self-assessment toward understanding the mathematics concept of junior school students. International Research Journal of Engineering, IT \& Scientific Research, 3(6), 116-124.

Mahendra, I. (2016). Contextual learning approach and performance assessment in mathematics learning. International Research Journal of Management, IT \& Social Sciences, 3(3), 7-15.

Mendoza, M., \& Rodríguez, M. (2019), Aprendizaje centrado en el estudiante desde la planificación en investigación. Cienciamatria, Vol. 6 (10) Pp. 560-572. DOI 10.35381/cm.v6i10.232.

Morales, L. M. V. (2010). School performance. Humanities, Technology and Sciences, 5.

Solarte, M. M. (2016). Reduction of poor performance and school failure through the implementation of a school of fathers and mothers. Spain: Join.

Widana, I. W., Parwata, I. M. Y., Parmithi, N. N., Jayantika, I. G. A. T., Sukendra, K., \& Sumandya, I. W. (2018). Higher order thinking skills assessment towards critical thinking on mathematics lesson. International Journal of Social Sciences and Humanities, 2(1), 24-32. https://doi.org/10.29332/ijssh.v2n1.74

Tumbaco, D. E. S., Albán, W. E. M., Ruperti, M. J. B., \& Palacios, D. E. P. (2019). Methodological strategies used in the learning of mathematics in the 8th year of EGB. International Journal of Social Sciences and Humanities, 3(3), 90-98. https://doi.org/10.29332/ijssh.v3n3.362 


\section{Biography of Authors}

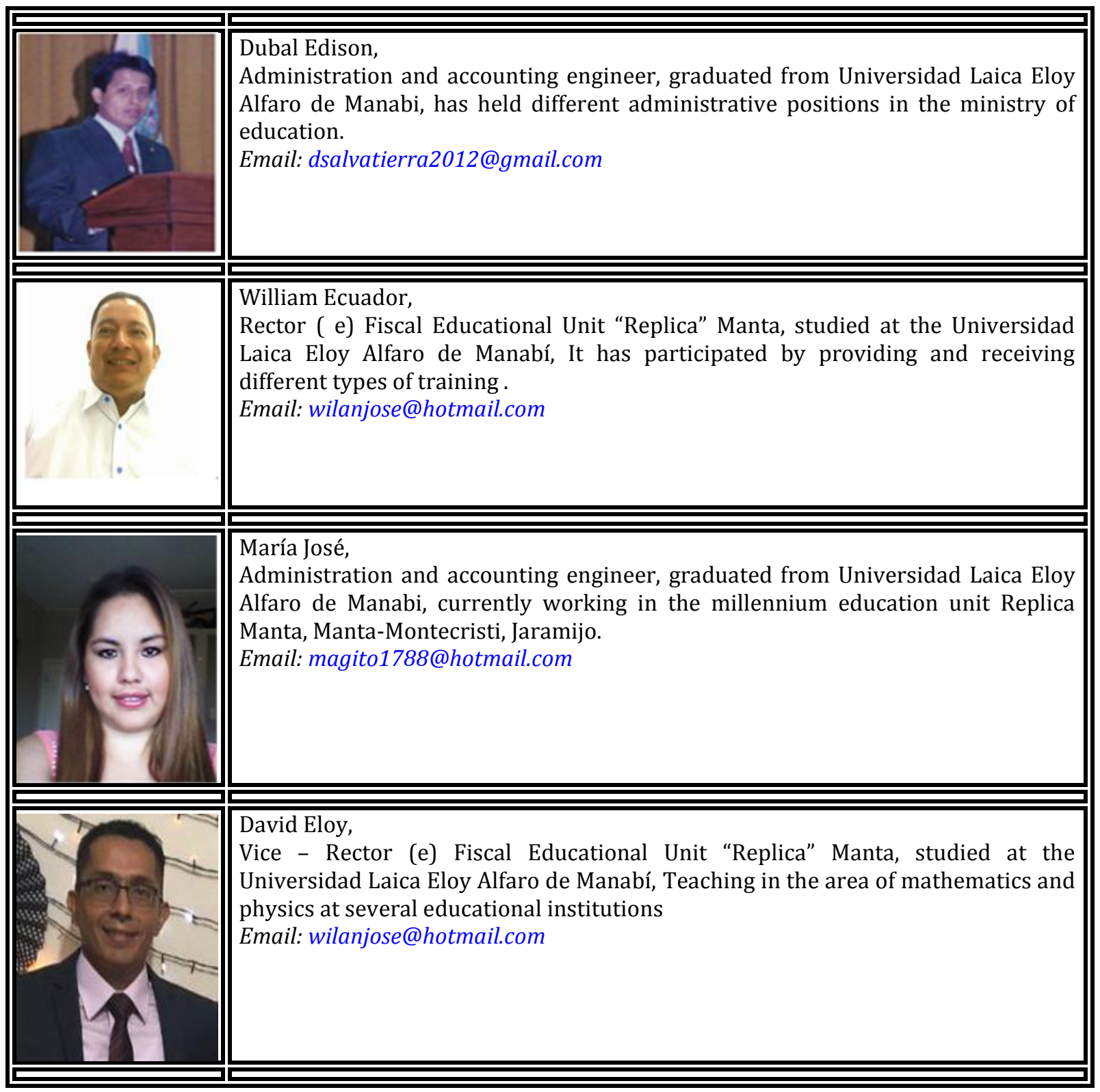

